\title{
A região como artefato: o Cariri na segunda metade dos Oitocentos
}

The region as artifact: the Cariri in the second half of the nineteenth century

Darlan de Oliveira Reis Junior*

\section{Resumo}

Na segunda metade do século XIX, a região conhecida por Cariri cearense, localizada no extremo sul da província do Ceará, destacava-se no sertão por ser conhecida como um "oásis" no semiárido, devido a sua vegetação, a presença de fontes d'água e solos férteis. Elaborou-se um discurso sobre a região ser o "celeiro" dos sertões. O presente artigo busca entender como, no espaço regional, o discurso sobre a natureza serviu de recurso político para o desenvolvimento da ideia de progresso por intermédio do trabalho que, no contexto histórico delimitado na temporalidade, refletia-se na submissão de trabalhadores livres em diversas condições econômicas e trabalhadores escravizados. Pretende-se analisar como as diferentes classes sociais estabeleceram suas identidades e vivências na região, as contradições resultantes da desigualdade social, bem como as práticas de controle estabelecidas pelos senhores e as diferentes formas de resistência dos trabalhadores.

Palavras-chave: História. Região. Trabalho. Agrário. Resistência.

\begin{abstract}
In the second half of nineteenth century, the known Cariri region, located in the south of Ceará, stood out in hinterland to be known as an "oasis" in semiarid area, due to its vegetation, presence of water fountains and fertile grounds. A discussion was established about that region being the "granary" of the hinterlands. This article intends to understand how in the regional area, the discussion about nature served as political asset for the progress idea development through labor, which in the enclosed historical context in the temporality, reflected on the free workers submission in several economic conditions and enslaved ones. It intends to analyze how different social classes have established their identities and experiences in the region, the contradictions arising from social inequality, as well as the control practices established by masters and different forms of workers resistance.
\end{abstract}

Keywords: History. Region. Labor. Agrarian. Resistance.

\section{Introdução}

O extremo sul do Ceará é comumente denominado como Cariri. Durante certo período, esse mesmo local recebeu um complemento ao substantivo próprio, o adjetivo novo. Em alguns casos, a denominação era operada no plural, "Cariris Novos", fazendo uma distinção em relação a outra região, localizada na Paraíba e conhecida por "Cariris Velhos”. Dessa maneira, parte do Ceará passou a se referir e a ser referida com tal epíteto. As origens da denominação do lugar tem relação com a nação Kariri que ali

\footnotetext{
* Doutor em História Social pela Universidade Federal do Ceará (UFC). Professor da Universidade Regional do Cariri (URCA).
} 
vivia e que posteriormente teve contato com os colonizadores ${ }^{1}$. Apesar da referência a um povo, com o passar do tempo, a região ficou marcada no discurso com outras identidades predominantes: a da natureza bela e com fartura das águas em pleno sertão, ou a da religiosidade de seu povo, notadamente testemunhada pelos romeiros que todos os anos seguem para Juazeiro do Norte, para visitar onde nasceu e viveu o Padre Cícero Romão Batista, ambas elaboradas no decorrer da segunda metade do século XIX.

Devido às grandes distâncias em relação ao litoral e à dificuldade na locomoção do semiárido, muito de sua história ganhou contornos peculiares. Um dos exemplos foi a busca pela autonomia política por parte da classe senhorial, traduzida na proposta de criação de uma nova província, separada do Ceará e retirando territórios deste e também das províncias de Pernambuco, da Paraíba e do Piauí. No decorrer dos séculos XVIII e XIX já se difundia a ideia de um espaço único em contraste com o restante do interior cearense e também das províncias vizinhas. A representação de um território como espaço privilegiado no interior do Ceará, devido ao solo fértil e à presença de fontes de água em contraposição à aridez do entorno, foi um importante instrumento político, utilizado pelas classes senhoriais na consolidação de seu domínio sobre o território. $\mathrm{O}$ Cariri, assim denominado, passou a ter uma existência histórica, de região vivida e representada. Ou seja, no decorrer da temporalidade, o espaço regional ganhou sentidos diversos, apropriações, usos e práticas que foram e ainda são objetos de disputa em vários campos como política, cultura, história, economia e representação simbólica.

No entanto, uma região não é um dado a priori, nem pode ser definida apenas a partir de critérios geográficos comumente identificados como "naturais". Não se trata de um espaço fixo, estático, aos moldes de uma "ilusão referencial” como critica Durval Albuquerque Júnior (2011, p.40) ao analisar certas concepções e discursos que se intitulam regionais. Um tipo de "História Regional" que participa da construção imagético-discursiva do espaço e mesmo quando trabalha com argumentos históricos, acaba validando-o como ponto de partida. Definindo-o, seja no âmbito geográfico ou no produtivo, mas como um dado a priori, tal procedimento anacrônico não leva em conta que tanto a época ou o próprio espaço não preexistem aos enunciados que os exprimem.

\footnotetext{
${ }^{1}$ Capistrano de Abreu explicou a situação da população indígena no século XVII: "O Ceará estava ocupado por Tupinambás ou Petiguares, ao Sul, chegados recentemente do Rio Grande do Norte, e por Tupiniquins ou Tabajaras, espalhados pela Ibiapaba, e residentes aí desde muitos anos, senão séculos, pois constituíam setenta aldeias. Eram numerosos os Tapuias, geralmente Cariris, primeiros habitantes do litoral, já então recalcados para o interior, exceto ao Norte, onde os Tremembés, também do tronco Cariri, dominavam as praias que vão do Camocim até além da Paraíba. A palavra Ceará (Siará) é legitimamente cariri, e as explicações até agora tentadas pelos tupis só satisfazem os próprios inventores". (ABREU, 1988, p.149).
} 
Ao pretender escrever sobre determinada região, o pesquisador deve levar em consideração a premissa de que nenhuma fronteira ou território pode se situar num plano a-histórico, pois ambos são produtos de uma rede de relações entre agentes que se reproduzem e agem com dimensões espaciais diferentes (ALBUQUERQUE JUNIOR, 2011, p. 35). No caso de uma pesquisa, a noção de região deve ser definida operacionalmente de acordo com certas variáveis e hipóteses, sem ter a pretensão de que seja a única maneira correta de recortar o espaço e determinar blocos regionais (CARDOSO, 1979, p.73). Ao fazer o recorte na delimitação do objeto, o historiador pode fazer coincidir seus procedimentos operacionais com o que já existe definido do ponto de vista político e administrativo, por exemplo. No caso do Cariri, a trajetória da identidade regional alterou-se, ganhou sentidos diferenciados conforme as percepções dos que viveram, vivem, estudaram ou estudam até hoje sua história. Nos dias atuais, compõe a estrutura administrativa do Estado do Ceará. No século XIX, a cidade do Crato destacava-se como a mais importante localidade, seja do ponto de vista econômico, ou político. Atualmente, parte do território do Estado do Ceará é denominado, descrito e identificado como "Cariri", seja do ponto de vista institucionaladministrativo, seja do ponto de vista das manifestações artísticas, de sua economia e práticas religiosas, além das peculiaridades geográficas. Administrativamente é identificado pelo governo como um "território de identidade", sendo uma subdivisão de uma Macrorregião de Planejamento, a "Macrorregião do Cariri/Centro-Sul". Assim, na política administrativa do governo do estado do Ceará, o Cariri é uma microrregião, como consta na documentação dos órgãos governamentais (INSTITUTO DE ESTRATÉGIA E PESQUISA ECONÔMICA DO CEARÁ, 2008).

Do ponto de vista cultural, toda uma produção artística e um discurso sobre a região são produzidos e difundidos por vários meios - imprensa, cordéis, canções, peças de teatro, discursos eleitorais, produções acadêmicas -, o que reforça a ideia de uma identidade própria e um sentimento de diferenciação quanto ao restante do Ceará e do país. Diferentes percepções e representações com um mesmo nome, que é constituído na ação de diversos sujeitos sociais, sendo produtor e produto de significado. Desse modo, o espaço vivido e representado tem um forte discurso regional e a ênfase nesse aspecto é marcante e teve uma elaboração especial no decorrer do século XIX.

Neste artigo será apresentado como a representação do Cariri foi construída a partir de determinada classe social e divulgada como sendo determinante para a formação de sua população. Para o entendimento desse processo, é preciso investigar os 
Oitocentos, pois foi naquele momento que as condições para essa operação política se tornaram possíveis. Um exemplo é o discurso sobre a identidade caririense, como se houvesse um sentimento caririense inato, que precisava ser rememorado e comemorado. Um século e meio depois, além do orgulho em "ser caririense", a reverência a um suposto passado glorioso, contribuiria, segundo determinada concepção, para o desenvolvimento regional. Além disso, serão apresentadas as formas de vivência e entendimento da vida social que não seguiam tal construção elaborada pela classe senhorial, o que ocasionava tensões e contestações às políticas dominantes no período.

\section{O Cariri entre o fato e o artifício: estratégias da classe senhorial}

Segundo Rogério Haesbaert (2010, p. 24), pensar em região é antes de tudo refletir sobre os processos de regionalização, sejam como dinâmicas efetivamente vividas e produzidas pelos grupos sociais, seja focalizando-os como simples procedimento metodológico ou instrumento de análise proposto pelo pesquisador. Quando a referência é o processo vivido e produzido pelos sujeitos sociais, a região torna-se então um fato. Quando é utilizada como mecanismo intelectual necessário para o entendimento, torna-se um artifício. Assim, a região é produto e ao mesmo tempo produtora. O Cariri pode assim ser entendido.

\footnotetext{
Foi elaborado, narrado, descrito e vivido por seus habitantes. Parte dessa narrativa o descreveu como peculiar, com tradições tão particulares que o diferenciariam das regiões circunvizinhas. Foi explicado como formador da identidade nacional ao dar sua contribuição ao país. Ao mesmo tempo, tornou-se um lugar de disputas entre diversos grupos sociais, lugar este que gerou riquezas para a classe senhorial através do trabalho de homens livres e dos escravizados, vivenciando a pobreza e miséria de amplos setores da população. Ou seja, é uma região de fato, vivida politicamente, cultural e economicamente. (REIS JUNIOR, 2014, p. 29).
}

A representação regional construída a partir da segunda metade do século XIX permitiu à classe senhorial elaborar uma autoimagem, elemento importante no pretenso projeto civilizador que dizia ser portadora. Os discursos não eram excludentes, nem justapostos. Na verdade, se completavam, na medida em que destacavam o espaço privilegiado pela natureza e as características de distinção da referida classe. Quem detinha o poder de delimitar, simbolizar ou nomear o espaço, procurava definir as distinções necessárias para o discurso político. Assim, a partir da identidade da região era elaborada a construção da imagem do Cariri como um local diferenciado no interior, 
um verdadeiro "oásis" em meio ao "sertão" cearense e vocacionado para as atividades agrícolas. No Cariri idealizado pela classe senhorial, aquele discurso foi de tal forma apresentado que passou a ser percebido como sendo a própria identidade regional, fortalecendo seu domínio de classe ${ }^{2}$. O que não significa dizer que todos os sujeitos sociais assimilaram ou aceitaram, da mesma maneira, os elementos que a compunham. Dissensos, resistências e outras formas de vivências existiram no mesmo espaço e fizeram o contraponto ao modelo idealizado pelos senhores.

Quais seriam os aspectos dessa identidade regional promovido pela classe senhorial na segunda metade dos Oitocentos? Pelo menos quatro aspectos se destacavam. A busca pela autonomia política como instrumento de afirmação de importância da região no cenário nacional e de consolidação de um projeto civilizatório; a afirmação de uma vocação agrícola determinada pelos recursos naturais; a imagem de uma classe senhorial paternal e branda no trato com as classes subalternas e por último, a difusão do estereótipo da índole propensa à vadiagem e à criminalidade dos setores da população que se recusavam ao trabalho subordinado àquela classe dominante. Os elementos formadores da identidade regional na perspectiva senhorial estabeleciam uma situação de desequilíbrio, pois a desigualdade social e a utilização dos trabalhadores numa situação de exploração eram assim justificadas.

A classe senhorial entendia como sendo a única capaz de levar em frente o processo civilizatório pois, na representação que fazia de si, destacava uma autoimagem em elevada valoração, com um sentimento de diferenciação aos setores populares. $\mathrm{O}$ quadro lhe parecia favorável. O histórico de domínio desde o início da colonização de certa maneira corroborava a ideia construída. Ali existiu um mundo rural, onde a formas de apropriação do espaço, sua transformação em propriedades juridicamente definidas, tinham como tradição o domínio sobre a terra, sendo este um dos elementos de desigualdade social e diferenciação de status e de prestígio. Além disso, parte da sociedade vivia na condição de proprietária de outros seres humanos, que naquele momento vivam na condição de escravizados. Compondo o quadro das diferenças e desigualdades, estava a distinção jurídica entre livres e escravos; o preconceito a partir

\footnotetext{
${ }^{2}$ Segundo Haesbaert, a identidade da região se refere às características de natureza, da cultura e dos habitantes que distinguem ou, de fato, podem ser usadas nos discursos da ciência, da política, do ativismo cultural ou da economia para distinguir a região das demais, através de classificações que excluem determinados elementos e incluem outros, expressando assim o poder de delimitar, nomear, e simbolizar o espaço e grupos de pessoas. A identidade regional envolve a identificação dos habitantes com sua região, tanto dentro quanto fora dela. Participam de sua construção, ativistas sociais, instituições e organizações, etc. (HAESBAERT, 2010, p. 119).
} 
da cor da pele, sobre negros, "mulatos" e todas as outras denominações para os que eram considerados "mestiços". Outro critério de diferenciação calcado na desigualdade era o de gênero, manifestado na subordinação exigida a muitas mulheres. Havia ainda a capacidade de alguns setores em acumular riquezas, seja por meio de privilégios concedidos pelo poder estatal, ou seja, pela herança; a possibilidade de participação na política através das eleições, baseadas num sistema censitário. Por fim, todo o discurso sobre a questão do estado, da autonomia provincial, da realização de obras públicas como estradas, prédios, açudes -, serviam aos propósitos de apropriação da classe senhorial, dos recursos públicos. O que se constituía e era apresentado como público emergia dos interesses particulares daquela classe (MATTOS, 2011, p.222). Formavamse assim os condicionantes naquela formação social. A conjuntura e as peculiaridades regionais, o seu desenvolvimento técnico e produtivo, suas relações com outros lugares e os recursos naturais passíveis de utilização na época, compunham as particularidades do Cariri.

Desse modo, em linhas gerais, o espaço vivido pela classe senhorial era representado como sendo potencialmente capaz de ser próspero, devido às possibilidades do uso dos recursos naturais exuberantes. A agricultura seria a mola propulsora desse desenvolvimento, desde que as classes trabalhadoras estivessem sob seu controle, disciplinadas. As propostas de autonomia não se concretizaram, porém, o monopólio das funções políticas institucionais era garantido, além da apropriação da riqueza gerada pelo trabalho dos homens livres pobres e dos escravizados, bem como do domínio sobre as melhores terras e recursos hídricos. Além disso, Celeste Cordeiro demonstra que, no Ceará, na segunda metade do século XIX, as características centrais da atividade política na província - a privatização da política a partir dos interesses familiares, o mandonismo local, a violência como forma eficaz de intimidação dos adversários - lastreada pelo poder econômico que possuíam, contribuíam para o estabelecimento do controle social sobre os trabalhadores (CORDEIRO, 2007, p.135161).

Um dos vetores explicativos propagados pelos grupos dominantes estava na diferenciação entre seu território e seu entorno. Um seria o "oásis", o outro, o "sertão". Os habitantes da região buscavam a diferenciação, não queriam que o local em que viviam estivesse associado à noção de atraso e de miséria. Assim como o dissociavam dos problemas inerentes à seca. Por isso apresentavam o Cariri como local de refrigério e de progresso: 
Não fica satisfeito o caririense quando alguém o chama de sertanejo, o seu Cariri de sertão. Não toma a palavra sertão em seu sentido mais amplo, na acepção da zona do interior, afastada da faixa litorânea. O Cariri, do Ceará, é uma espécie de zona da mata pernambucana, ou dos brejos na Paraíba. É o verdadeiro oásis cearense como muitos o denominam. É uma ilha verdejante cercada da zona sertaneja criadora. (FIGUEIREDO FILHO, 2010a, p. 21).

A diferenciação entre o "oásis" e o "sertão" servia aos propósitos políticos da classe senhorial, antes mesmo da questão das secas serem tratadas como um problema nacional, se tomarmos o que ocorreu a partir do ano de 1877 como a referência para esse problema. Em momentos anteriores, as autoridades políticas operavam com o discurso sobre a natureza para atingir seus propósitos, com a já citada distinção entre o Cariri e os sertões. A Câmara de Vereadores do Crato reforçava a ideia de que a cidade seria privilegiada.

\begin{abstract}
As precisões mais urgentes deste municipio continuão a ser, as que por esta mesma Camara ja forão ponderadas a V. Exc. ${ }^{a}$ nos officios $n^{\text {os }} 9$ de 28 de Abril de 1845, e 33 de 11 de Março do anno passado: a industria geral delle he Agricula, e está muito atrasada, sendo o principal motivo deste atrazo, as pessimas estradas que partem desta Villa para as diferentes partes da Provincia, e das circunvizinhas, muito principalmente a do Ico por onde entra todo Comercio de fazendas seccas, e mulhadas, que paraliza no inverno pellas intermicencias do Rio Salgado. Neste municipio ameno e bello, $\mathbf{E x}^{\mathbf{m o}}$ Snr, naõ ha percizões de assudes, por ser todo o termo cortado de Ribeiras, e suas nativas aguas depois de banharem vastas planices cobertas de plantações, reunem-se e formão as correntes Batateira, Salamanca e Inhuma. A caza das seções desta Camara he sofrivel, e naõ está em estado que indique ruina; outro tanto porem se naõ for desdizer das Cadeias desta Villa, que sendo huma das mais seguras das da Provincia, está contaminada de hum formigueiro, que amiassa ruina. (ARQUIVO PÚBLICO DO ESTADO DO CEARÁ, 1847 - grifo meu). ${ }^{3}$
\end{abstract}

Da afirmação de suas peculiaridades naturais, os vereadores postulavam mais recursos e obras públicas. No caso, a melhoria das estradas para facilitar o comércio. As câmaras municipais não detinham grandes recursos financeiros. desse modo, solicitavam o apoio financeiro do governo provincial. entre as proposições, a mais polêmica era a da autonomia política, por meio da criação de uma nova província. Era polêmica porque o Brasil vivera no período regencial uma série de rebeliões e tentativas de maior autonomia, sendo algum desses movimentos diretamente promovidos pelas classes senhoriais locais, enquanto outros tinham um caráter nitidamente popular, o que assustava não só o poder central, como os próprios membros das oligarquias regionais.

\footnotetext{
${ }^{3}$ ARQUIVO PÚBliCO DO ESTADO DO CEARÁ. Câmara Municipal do Crato. Ofício da Câmara Municipal do Crato ao Presidente da Província do Ceará, Ignacio Corrêa de Vasconcelos, em 13 de abril de 1847. Caixa 34, 13/04/1847.
} 
Os vereadores do Crato tinham a posição em defesa da criação da província como um ponto chave na resolução dos principais problemas.

\begin{abstract}
Esta Camara já fez levar ao conhecimento de VEx ${ }^{\text {ca }}$ quaes as necessidades mais urgentes de seu Municipio, e ainda persiste no sentimento de dizer ao Governo que temos falta de Cadeia, Matriz, Casa de Camara, Instrucção primaria, Estradas, Comercio, Policia, falta tudo afinal quanto necessario se torna para o incremento do mais bello Paiz do Ceara, e a Camara julga que o meio mais facil de remediar todos esses males he a realização da pretendida nova Provincia dos Cariris Novos, com o que teremos hum Governo, que sendo testemunha ocular de nossas precizões poderá, com conhecimento de cauza prover sobre as precizões mais urgentes do paiz. A secca fez migrar para este termo melhor de vinte mil pessoas; e o Cariry pode sustentar dessa infinidade de retirantes, sem que fizessem a fome, graças aos belos recursos que possuimos, os quaes a naõ serem estragados pelos ladrons indomaveis, não teriamos nada a reciar de prezente, pela falta de Chuvas, que ameaça parte de nossas Searas, por terem sido plantadas em Março. Nós vemos que huma pequena parte da população imprega-se na Agricultura, e que o paiz acha-se innundado de Vadios e ladrons, parte dos quais vindos de fora, cossados pela secca, fizerão aqui causa Comum com os que ávião, e fazem huma total inversaõ dos costumes, que muito tememos, sem que a Policia nesta parte nada possa fazer pela dessidida falta de força regular, que se impregou contra os assassinos e malfeitores, não podendo achar-se recurso na Guarda Nacional pelo seu total desmoronamento. (ARQUIVO PÚBLICO DO ESTADO DO CEARÁ, 1846 - grifo meu). ${ }^{4}$
\end{abstract}

Os senhores percebiam a questão da seca em outras regiões como uma ameaça, com a migração de milhares de pessoas, ao mesmo tempo em que afirmavam que apenas uma pequena parte da população empregava-se na agricultura. Parece uma contradição reclamar da falta de braços para o trabalho, ao mesmo tempo em que informavam da chegada de milhares de pessoas sem ter o que fazer. Naquele discurso, o espaço era utilizado como ferramenta de ação política. A ênfase na regionalidade justificava a ação do Estado, e a ideia de maior autonomia tinha repercussão entre os setores da elite caririense. O sentimento de diferenciação e a ideia de autonomia que possibilitasse a resolução de problemas, além de promover um suposto desenvolvimento, propiciava uma movimentação política que propunha, como ápice de sua plataforma, a criação de uma nova província no interior do Brasil, a "Província dos Cariris Novos".

\footnotetext{
${ }^{4}$ ARQUIVO PÚBLICO DO ESTADO DO CEARÁ. Câmara Municipal do Crato. Relatório da Câmara Municipal do Crato ao Presidente da Província do Ceará, Ignacio Corrêa de Vasconcelos, em 11 de maio de 1846. Caixa 34, 11/05/1846. fls. 1-2.
} 
Não aventamos idéias novas. As diversas Camaras da comarca do Crato, e muitos dos municipios preditos, tem instantemente pedido ao Corpo Legislativo a adopçaõ de tal ideia, e há bem pouco novas petições lhe foram feitas neste sentido. (CENTRO DE DOCUMENTAÇÃ̃O DO CARIRI, 1855). ${ }^{5}$

Lideranças políticas, por meio do jornal O Araripe, defendiam a criação da nova província. Para elas, com seu surgimento, a justiça seria mais rápida, a repressão aos crimes mais eficiente, as atividades econômicas ganhariam um novo impulso e ao final, poderiam realizar uma reforma de costumes, contribuindo para a elevação da unidade brasileira à altura dos "povos morigerados". E um argumento levantado era o da viabilidade econômica. O "império da produção" teria amplas condições de se tornar uma província.

\begin{abstract}
A realisar-se sua erecçaõ naõ seria a provincia em questaõ uma dessas, que á mingua de recursos financeiros vegetaõ na miseria, e soem esmolar subvenções dos cofres geraes, naõ já para suas obras e empresas de vulto, mas até para occorrer ás despesas que fasem com o pessoal de sua administraçaõ; ao contrario podendo em seu começo appresentar uma receita equivalente a suas dispesas, em breve atingiria a uma disponibilidade, que a habilitasse, a faser apparecer a arte, onde uma naturesa, que se ostenta prodiga, emprasa os homens a secunda-la. Era desses milhoes de animaes, que criaõ suas vastas campinas; era dessas innumeras e variadas produções de uma regiaõ sobremodo fertil, que compartilha todos os climas, e vê brotar o fruto de todas as zonas; era finalmente de um commercio todo de exportaçaõ em favor do paiz, e susceptível de um desenvolvimento e animaçaõ sem lemites, que esta provincia tiraria meios de manter-se, e o que mais é, ellevar-se a altura das mais adiantadas do imperio: recursos estes, que entretanto, assim segregados e entregues á suas proprias forças, estaõ perdidos para estes municipios e nullificados para suas metropoles. (CENTRO DE DOCUMENTAÇÃO DO CARIRI, 1855). ${ }^{6}$
\end{abstract}

Segundo José de Figueiredo Filho, a proposta de criação da província era mais antiga. No ano de 1839 havia sido apresentado um projeto de lei pelo Senador José Martiniano de Alencar, estabelecendo uma província que teria uma grande abrangência.

Art. $1^{\circ}$ - Fica criada uma província que se denominará Província do Cariri Novo, cuja Capital será a Vila do Crato.

Art. $2^{\circ}$ - Esta Província se formará:

$\S 1^{\circ}$ - Dos Municípios do Riacho do Sangue, Icó, Inhamuns, São Mateus, Lavras, Jardim e Crato, da Província do Ceará.

$\S 2^{\circ}$ - Dos Municípios do Rio do Peixe e Piancó, da Província da Paraíba.

$\S 3^{\circ}$ - Do Município de Pajeú das Flores compreendidos no antigo Julgado de Cabrobó, da Província de Pernambuco.

$\S 4^{\circ}-$ E do Município de Piranhas, da Província do Piauí. (FIGUEIREDO FILHO, 2010b, p. 81).

\footnotetext{
${ }^{5}$ CENTRO DE DOCUMENTAÇÃO DO CARIRI. Jornal O Araripe. O Araripe, Cidade do Crato, 07 jul. 1855. p. 2. [Coleção Digital].

${ }^{6}$ CENTRO DE DOCUMENTAÇÃO DO CARIRI. Jornal O Araripe. O Araripe, Cidade do Crato, 14 jul. 1855. p. 1. [Coleção Digital].
} 
A classe senhorial desenvolveu um projeto de fortalecimento de seu poder por meio de diferentes estratégias, entre elas, a de aumentar o seu poder político com a criação da nova província. O que traria uma arrecadação, efetivos policiais, novos empregos públicos, enfim, um maior poder para aquela classe social. Em que pese o projeto de 1839 não ter sido concretizado, permaneceu a bandeira da autonomia. Um exemplo é o editorial do jornal O Araripe, no ano de 1858, como se fosse porta-voz de um sentimento de toda a população.

\begin{abstract}
Na verdade, depois de nossa émancipaçaõ politica, nenhuma causa despertou já tantas sympathias, no meio das populações que habitaõ este canto do Imperio. A creaçaõ é uma idéa popular, onde se reunem os homens de todas as crenças, um constante objeto de nossos votos; e é de sua realisaçaõ que, a justos titulos, fasem todos pender os nossos mais caros interesses, os interesses do povo e do governo, os interesses do commercio e da policia, os interesses da educaçaõ e da riqueza. (CENTRO DE DOCUMENTAÇÃO DO CARIRI, 1858). ${ }^{7}$
\end{abstract}

Além da tentativa de efetivação da nova província, penso que é plausível a hipótese de que o reiterado discurso sobre tal questão contribuía para o fortalecimento da ideia de região, servindo aos interesses dos senhores. Esse discurso tentava associarse ao conjunto da população. O "oásis", o "celeiro", o "império da produção", vocacionado para a agricultura, que tinha todas as condições de ser província e caminhar para o progresso civilizatório. Palavras que sempre retornavam, serviam de argumento, justificavam ações. Um artifício da classe senhorial, classe que utilizou de forma eficiente a ideia de um "Cariri oásis", de tal maneira que a construção ideológica foi aperfeiçoada no decorrer do tempo, chegando ao século XX como se fosse um dado concreto, inclusive formador da identidade regional. Um procedimento operacionalizado através das classificações, excluindo determinados elementos e incluindo outros, traduzindo o espaço de identidade cultural em representatividade política, articulado em função de interesses específicos, por uma "fração ou bloco de classe que nele reconhece sua base territorial de reprodução" (HAESBAERT, 2010, p. 120).

O estereótipo da inferioridade dos trabalhadores estava enraizado na cultura política da classe senhorial. No ano de 1870, o presidente da província, João Antonio de Araujo Freitas Henriques, ao defender a entrada de imigrantes, com vistas a resolver o problema provocado pela "questão servil", afirmou que os estrangeiros tinham uma

\footnotetext{
${ }^{7}$ CENTRO DE DOCUMENTAÇÃO DO CARIRI. Jornal O Araripe. O Araripe, Cidade do Crato, 26 jun.1858. p. 1. [Coleção Digital].
} 
homogeneidade de costumes, de identidade e de religião, e que isso seria muito favorável para o Ceará, em contraposição aos locais (PROVÍNCIA DO CEARÁ, $1870)^{8}$. Em sua fala à assembleia provincial, o presidente tinha anexo o relatório do chefe de polícia, Henrique Pereira de Lucena, que descrevia seu entendimento sobre a motivação dos crimes no Ceará, imputando-os aos hábitos de determinado setor.

$\mathrm{O}$ ataque, porém, á propriedade, no qual sempre entra a premeditação e o cálculo, é um mal quasi incurável; porque importa a hedionda ociosidade com o cortejo de todos os vicios e más tendencias; é a completa negação do trabalho; o espírito de perturbação latente á ordem social, cujo principal garante só póde ser o fructo do labor individual, o commodo licito da familia. (PROVÍNCIA DO CEARÁ, 1870). ${ }^{9}$

No Cariri, os estereótipos também eram difundidos, assim como a tentativa de entender as condutas. Carta publicada em O Araripe no ano de 1856 criticava o gosto pelo jogo, tanto dos ricos quanto dos pobres. Seu autor usou apenas um codinome, "o sobrinho do sr. K”, para se identificar. Em outros números, um autor se identificava apenas como "K" e também escrevia cartas criticando os modos e costumes locais. No entanto, suas críticas eram mais severas para os empobrecidos. Voltando à carta do "sobrinho do sr. K", este alegava que temia represálias pelo teor ácido de suas críticas. Em determinado trecho, atacava a prática dos jogos e dos sambas ${ }^{10}$.

O povo do Cariry, por isto que é doptado de uma vivacidade sem limites, entrega-se à toda sorte de distrações, não podendo estar quieto, inda quando de qualquer passo que tente dar, possa resultar-lhe uma queda. Quanto mais descemos pela escalla social mais observamos essa actividade, que absorve tudo. Assim, nos dias santificados para os que trabalhão, e nos outros seis da semana para os que fogem de occupações proveitosas, os sambas e os jogos estão em permanência. E' domingo. Os ricos jogão a espadilha, as mulheres a suèca o pobre o vinte e sete, o captivo ou o frécha ou o cacete. Ora, os ricos teem lá sua rasão; porem os pobres se estão fasendo o maior mal, ja isso não é tão proveitoso. Mas demos de barato que em tal dia o custume tenha sancionado os jogos e passatempos; e ainda mais que os ricos (si há gente bastante rica para jogar nos 25 domingos e tantos outros dias santificados do anno) possão agoentar essas sangrias; como se pode porem a D. Policia deixar ficar queda á vista do abuso que fas a nossa classe pobre, a pobrissima, a mendicante? Ah! é muita encuria, é uma falta immensa, deixar que assim se estrague noite dia nos lugares mais publicos um povo numeroso que fas da sua profissão de jogos, que emigra do Crato para a Barbalha, e da Barbalha

\footnotetext{
${ }^{8}$ PROVÍNCIA DO CEARÁ. Fala de abertura da $1^{\text {a }}$ Sessão da $18^{\circ}$ Legislatura feita pelo Presidente da Província do Ceará, João Antonio de Araujo Freitas Henriques, em 01 de setembro de 1870. p. 36. Disponível em: 〈http://www.crl.edu/brazil/provincial/cear\%C3\%A1>. Acesso em: 12 mar. 2012.

${ }^{9}$ PROVÍnCIA DO CEARÁ. Relatório do Chefe de Polícia, Henrique Pereira de Lucena, anexo à fala de João Antonio de Araujo Freitas Henriques. 1870. Disponível em: <http://www.crl.edu/brazil/provincial/cear\%C3\%A1>. Acesso em: 12 mar. 2012.

${ }^{10}$ Os sambas eram as festas com música, dança, bebida e comida realizada nos terreiros das casas dos trabalhadores no Cariri.
} 
para o Crato procurando somente jogar; que haja gente que adquira celebridade nesta traficancia; que os matutos joguem nas feiras o dinheiro, a carga, o cavallo, a rede, e até o chapeo! [...] Mas é isto que o q' vemos diariamente no Crato mesmo na prisão da salla Erre, na Barbalha no Jardim em Porteiras, em cada villa, em cada povoação ou sitio, em cada canto finalmente. Cumpre que a policia acabe com isto ao menos para que daqui a pouco se não supponha que jogar dinheiro é profissão licita; porque, se isto se deixa encasquetar ao povo, adeos enchada! (CENTRO DE DOCUMENTAÇÃO DO CARIRI, 1856). ${ }^{11}$

O apelo à força policial para que reprimisse os setores populares empobrecidos era frequente. Em qualquer localidade, fosse um sítio, ou uma vila, deveria ser coibida a prática popular do jogo e da festa. Na medição social que fazia, o autor da carta entendia uma escala social em que os mais pobres seriam os maiores detratores das atividades que ele entendia como sérias. Dessa forma, aqueles homens e mulheres acabariam se contrapondo ao propósito da vocação regional, tantas vezes apregoado, que seria o da produção agrícola.

\begin{abstract}
A agricultura, que taõ lentamente progride nos paises em que mais prospera, conserva-se nesta comarca completamente estacionaria, posto que a produçaõ tenha acompanhado o incremento da populaçaõ, com tudo a quantidade e qualidade dos produtos agriculas, naõ corresponde a extrema uberdade do solo, nem, a relativa densidade de sua populaçaõ, e isso porque a antiga rotina pesa com toda sua força de inercia sobre a agricultura. Nem um processo aperfeiçoado dos mais communs em outro qualquer paiz, tem substituido aos imperfeitissimos processos tradicionaes de nossa terra, atraso sem duvida divido a difficuldade, que tem o nosso agricultor de obter conhecimentos profissionais, que o habilitem para subtrair-se ao jugo da velha rotina. Alem disso as difficuldades com que lutaõ nossos agricultores pela falta de braços, que é bastante sensível entre nós, em rasaõ da escacez dos escravos; via de transporte; exorbitante pressaõ de juros; convencional recusa da populaçaõ a certos trabalhos agriculas, que julgaõ distinctivos da escravidaõ; e afinal as incalculaveis e offensivas destruições das plantas, operadas pelos gados sem pastores: tudo isso concorre para o estado estacionario de nossa agricultura. (CENTRO DE DOCUMENTAÇÃO DO CARIRI, 1856 - grifo meu). ${ }^{12}$
\end{abstract}

A carta acima, assinada por A. G., leitor de $\mathbf{O}$ Araripe revelava a preocupação com a questão da mão de obra. Lamentos e explicações sobre as possíveis causas da recusa da população em servir. Sabia o autor que homens livres não desejavam ser comparados aos escravos e nem realizar tarefas que, geralmente, estavam associadas a aquele grupo. Nesse tipo de construção ocorria uma associação entre os problemas

\footnotetext{
${ }^{11}$ CENTRO DE DOCUMENTAÇÃO DO CARIRI. Jornal O Araripe. O Araripe, Cidade do Crato, 10 maio 1856. p. 2. [Coleção Digital].

${ }^{12}$ CENTRO DE DOCUMENTAÇÃO DO CARIRI. Jornal O Araripe. Carta de A.G., morador de Missão Nova, enviada em 29 de fevereiro de 1856. O Araripe, Cidade do Crato, 1 mar. 1856. p. 2. [Coleção Digital].
} 
econômicos, sociais e de criminalidade com uma suposta "natureza" humana essencializada. No que diz respeito aos livres que fossem pobres, aos escravizados ou aos povos indígenas, eles eram associados à indolência e à vadiagem. Combinado a essa associação, estava vinculada a suposta "vocação" do lugar, fazendo-se a referência à fertilidade do solo, ou à existência de fontes de água, chuvas regulares e singularidades do relevo. No entanto, as expectativas dos senhores muitas vezes eram frustradas pelas resistências dos trabalhadores.

\section{Diferentes experiências, a região como artefato: trabalhadores do Cariri}

O que imaginava e compreendia a classe senhorial sobre os trabalhadores e o que eles imaginavam e compreendiam sobre si mesmos não eram as mesmas coisas. Várias práticas e comportamentos que eram vistos pelos senhores como ociosidade, vadiagem, fanatismo, incapacidade, estupidez, tendência para o crime, má-fé, ou alguma outra má qualidade intrínseca, não eram assim vistos por quem vivia do seu próprio trabalho. Mesmo com todas as suas diferenças - de condição jurídica, atividade, local de moradia, religião, gênero, situação econômica ou cor -, havia uma coisa em comum aos diversos segmentos de trabalhadores, que era o fato de comporem as classes subalternas. O fato de viverem nessa condição, não necessariamente fazia surgir uma possível solidariedade, por exemplo, entre escravizados e livres pobres. Os atos de ajuda, companheirismo ou ação em comum, dependiam de outras questões que dizem respeito aos compromissos morais, aos costumes, aos laços de parentesco, às experiências, enfim, devem ser avaliados no contexto histórico e não traduzidos em uma generalização apriorística.

$\mathrm{Na}$ história sobre o Cariri cearense, além do discurso sobre a vadiagem, também a vida mais simples e até a religiosidade dos mais pobres foi vista como fator depreciativo. Suas atividades, trajetórias, produções materiais e imateriais, suas maneiras de vestir, habitar e se alimentar, foram sendo esquecidas, ou consideradas imprevidentes, dependendo da situação. De qualquer modo, quero destacar que a percepção sobre a fuga ou do "pouco" trabalho estava presente nas observações do início do século XIX. E se manteriam por todo aquele século e o seguinte. O que a classe senhorial não queria explicar era o fato de que, se a população era "vadia", como explicar que conseguia sobreviver? A verdade é que tentavam desqualificar os hábitos de trabalho da população rural no Cariri, que eram baseados na agricultura de 
subsistência, em pequenas posses quando possível, pois o fato concreto é que os homens livres pobres preferiam essa condição a ter que trabalhar como alugados, por jornada, ou como agregados, vivendo de "favor" nas terras dos senhores.

A difusão de estereótipos consolidou-se na formação de preconceitos e do senso comum sobre a vida dos moradores de origem mais humilde e que viviam das atividades ligadas ao mundo rural. O campo e a cidade são realidades históricas em transformação, tanto em si próprias quanto em suas inter-relações, mas a ideia de campos e cidades como realidades dicotômicas ainda conserva força acentuada em diferentes culturas. No entendimento de Raymond Williams (1989, p.387), essa percepção dá origem à redução da variedade histórica de formas de interpretação aos chamados símbolos e arquétipos, dando status básico psicológico ou metafísico, de algo que é social. Dessa raiz surgiram idealizações sobre uma suposta vida bucólica nas áreas rurais em contraposição ao ritmo das cidades, ou sobre o caráter do "homem do campo", homogeneizando os indivíduos numa espécie de modelo ideal de camponês, ou de homem pobre livre. No caso brasileiro, a denominação que variava conforme a região, mas sempre com um sentido depreciativo quando a referência são os mais pobres. "Caipira", "matuto", "cabra", “caboclo" ou "roceiro" são exemplos da difusão de estereótipos, pois foram expressões que surgiram a partir de uma suposta característica intrínseca a um grupo, ora fazendo menção à cor da pele, ou à mestiçagem, ora fazendo menção à rusticidade, inferioridade ou ignorância daqueles tipos. No Cariri não foi diferente.

Pode o agregado plantar seu roçado de cerais, no inverno, em terras arrendadas, fora da zona de água regadia. Quando amaina a tempestade dos anos ruins e há fartura na terra nordestina, então, o morador torna-se um perdulário. Ainda não aprendeu a ser previdente, como o agricultor europeu que teve como amostra a escola dura das dificuldades. Gasta quase tudo o que possui, quando casa uma filha ou celebra outro acontecimento. As festas dançantes, puxadas à sanfona, se disseminam em brejos e pés de serra. Mesmo nas épocas normais ou de crise, o homem do campo não esquece a dose de pinga, da mesma forma que sua mulher e filhas não passam sem o fumo para o cachimbo. As ligações do agregado com a terra a cada dia se enfraquecem mais. Por qualquer coisa, arruma os cacarecos e muda-se para outra terra. Poderá a sua vida melhorar dentro da atual ordem de coisas? (FIGUEIREDO FILHO, 2010a, p. 30-31).

Figueiredo Filho escreveu o trecho acima no ano de 1958. Para o historiador cratense, as práticas dos agregados vinham de tempos distantes e permaneciam como marca distintiva daqueles trabalhadores. A prática historiográfica durante certo tempo priorizou os "grandes nomes", os colonizadores, os detentores dos cargos políticos, os homens mais ricos e poderosos, os membros do clero e os chamados intelectuais, muitas 
vezes bacharéis em Direito, Medicina e Farmácia. Nessa lógica, teriam sido eles que por meio de sua iniciativa, da inteligência e da capacidade política, do amor ao lugar em que viviam, desenvolveram a região do Cariri. As classes subalternas, quando muito, contribuíam com alguns atributos de coragem, mas geralmente ligados à resistência contra as secas que assolavam os sertões, o fervor religioso e em alguns casos, a gratidão aos senhores. No mais, suas atividades econômicas quando levadas em consideração, eram destacadas sempre com algum sentido pejorativo, suas atitudes descritas como "perdulárias". E as tensões relativas à desigualdade social e à exploração do trabalho simplesmente desaparecem nesse tipo de escrita.

Essas abordagens não consideram a desnecessidade de trabalhar o tempo todo, todos os dias do ano, na produção agrícola voltada para um suposto mercado. Desnecessidade esta que é comum aos trabalhadores do campo brasileiro, como afirma Antonio Candido (2010, p. 100-103). As atividades da caça, do artesanato, das possibilidades que os recursos naturais oferecem, os cultivos que lhe são suficientes para si e para sua família, faziam daqueles que conseguissem produzir mais livremente sujeitos que não tinham a mesma necessidade de trabalho dispendido como esperavam os senhores. Além disso, Candido aponta que, muitas vezes, os trabalhadores tinham um controle precário sobre a terra, correndo riscos de perdê-la a qualquer momento. Assim, buscavam sempre a colheita que pudesse ser feita em poucos meses, como as de milho e de feijão. A consequência era uma margem ampliada para o descanso, oportunidade para a caça, coleta, pesca, indústria doméstica - no setor da cultura material. E para a cooperação, festas, celebrações, que mobilizavam as relações sociais, o que, segundo Cândido, caracterizaria sua cultura, não devendo, portanto, ser julgado no terreno ético, isto é, ser condenado ou desculpado. Não era assim que pensavam certos grupos sociais no Cariri. A visão que tinham sobre os trabalhos realizados por conta própria, ou das atividades não tuteladas pelos senhores ou pelo estado, recebiam críticas contundentes.

\footnotetext{
Quinta e sexta-feira desta semana o rio desta cidade esteve quase secco, e a mesma agoa, que se tirou para beber, estava em más condicções. Demais os pescadores, que não são mais que uns grandes vadios que procurão matar o tempo com qual quer occupação pro frivola que seja, acabarão de emporcalhar o rio e a embaraçarão cada vez mais a lavagem de roupa. Entretanto a Policia e a Municipalidade não attenderão ainda as reclamações do Povo. Com tudo clama-se e clamar-se-ha pelas providencias necessarias, porque ainda muito confião na justiça da Policia e da Municipalidade. Os que soffrem. Crato 28 de Outubro de 1870. (CENTRO DE DOCUMENTAÇÃO DO CARIRI, 1870). ${ }^{13}$
}

${ }^{13}$ CENTRO DE DOCUMENTAÇÃO DO CARIRI. Jornal A Voz da Religião. A Voz da Religião, Cidade do Crato, 30 Out. 1870. p. 3. [Coleção Digital]. 
As cartas e editoriais do jornal O Araripe, já citados, também confirmam essa predisposição em condenar o modo de vida dos trabalhadores caririenses. Ao alegarem que seus hábitos os encaminhavam para a vadiagem e que a "facilidade com que provinham suas necessidades" os tornaria insubmissos, a classe senhorial entendia que aquele modo de vida era incompatível aos seus propósitos (CENTRO DE DOCUMENTAÇÃO DO CARIRI, 1859) ${ }^{14}$. Boa parte da população trabalhadora no Cariri era composta por homens e mulheres que se dedicavam à agricultura. No que diz respeito ao tipo de mão de obra, as condições variavam desde o escravizado até o camponês com alguma condição material superior aos seus iguais, entremeados por outros tipos de trabalhador livre, vivendo em diversos níveis de pobreza e submetido a diferentes regimes de trabalho.

Como os trabalhadores entendiam o espaço em que viviam? Até que ponto os componentes de uma suposta "identidade regional" caririense, elaborados e difundidos pela classe senhorial, faziam parte da sua própria identidade? E se não faziam, quais seriam os elementos que compunham o seu mundo? Conforme foi analisado, a categoria era heterogênea. No entanto, alguns elementos em comum conformavam uma cultura que lhes era própria, sua "experiência", padrões de conduta e valores.

Nem sempre havia uma avaliação pejorativa sobre os hábitos da população trabalhadora no Cariri. Francisco Freire Alemão narrou uma festividade ocorrida na localidade de Vargem Grande, no caminho entre a cidade do Crato e a vila de Lavras da Mangabeira. Tratava-se de um casamento "na casa de uns pardos matutos", sobre o qual Freire fez as seguintes observações:

\begin{abstract}
Quando lá chegamos - sete horas da noite - já estava feito o casamento, que foi feito em casa, pelo padre que também assistia ao samba. A casa coberta de telha fosca, chão de terra com uma comprida varanda, onde estava armada uma mesa de mais de 40 palmos. As mulheres sentadas todas do lado de dentro, os homens do lado de fora; e nós fomos todos convidados a tomar assento, mas só tomamos uma xícara de café, além de um copo de cerveja preta que me foi oferecido logo que me apeei. Provei aluá de milho, assim como tomei alguns tragos de genebra no mesmo copo onde bebia outra gente, e que com a mais ingênua sem-cerimônia me ofereciam. [...]Acabada a mesa formou-se o samba no terreiro. Estenderam uma rede nos esteios da varanda e instaram comigo para que me sentasse nela, o que não aceitei, e não fui mal no negócio porque puseram-me em uma cadeira de couro em lugar onde estava ao lado das senhoras, com quem eu conversava. [...] Com bancos se formou um quadrado bastante grande, onde se sentavam nos três lados de fora homens, do lado da varanda outro banco onde estavam os noivos, as meninas de que já falei, mais umas mulatas. As senhoras ficaram sentadas dentro da varanda. (ALEMÃO, 2006, p. 195-196).
\end{abstract}

\footnotetext{
${ }^{14}$ CENTRO DE DOCUMENTAÇÃO DO CARIRI. Jornal O Araripe. O Araripe, Cidade do Crato, 02 abr. 1859. p.1. [Coleção Digital].
} 
Freire Alemão observou ainda a presença do juiz municipal, do escrivão, de "senhoras algumas brancas, e das melhores famílias do lugar". Segundo ele, depois de sua saída, por volta da meia-noite, a festa teria prosseguido com queima de fogos e dança de quadrilha. Sua avaliação do evento foi positiva e através de seu relato pode se notar a característica aludida anteriormente, como o caráter coletivo das atividades. Maria Isaura Pereira de Queiroz (1973) apresentou as diversas orientações sobre o que seria o campesinato, as distinções entre o próprio grupo social - de riqueza, de acesso à terra, dentre outras -, sua presença no Brasil em diferentes períodos históricos, além de considerar que é impróprio falar em "sociedades camponesas". Para Queiroz, o que existe no mundo rural é um campesinato que ocupa uma posição de subordinação social, econômica e política, muito embora em vários países, durante muito tempo, tenha sido a massa majoritária da população. Considera que a categoria denominada "sitiante" também pode ser incluída na de camponês, não sendo restrita ao estado de São Paulo. E deixa claro que é preciso, na pesquisa, identificar os sitiantes que se tornaram clientela dos fazendeiros, aqueles que tinham maior autonomia, e os trabalhadores que tendo origem no campesinato, acabavam perdendo o acesso à terra $\mathrm{e}$ tornavam-se moradores, agregados ou jornaleiros (QUEIROZ, 1973, p. 35-37).

Ao habitar em zonas de sítios dispersas em torno de um pequeno núcleo central - que pode ser uma capela, uma venda de secos e molhados, duas ou três habitações -, os camponeses viviam do trabalho quase que exclusivamente com sua família, no que tanto Antonio Candido como a própria Maria Isaura Queiroz denominaram bairros rurais. No Cariri, o termo mais utilizado para essa configuração é sítio. Faço uma observação para o significado da palavra sítio, no entendimento que se tem dela na região. Tanto pode ter o mesmo sentido que o de bairro assume em São Paulo, ou seja, uma localidade no meio rural, formando uma comunidade camponesa, como também a unidade de moradia e produção de uma família:

Essas propriedades menores, percebidas em toda a região, eram denominadas de sítios. Em virtude de possuírem produções bastante diversificadas, para consumo familiar e venda no mercado interno ou externo, a existência dos sítios na região permitia a sobrevivência do pequeno proprietário, além do que não implicava numa grande disparidade na divisão social do trabalho. (CORTEZ, 2008, p. 53).

Retorno ao primeiro significado apresentado: o de uma comunidade. A distância é fator de limitação do bairro ou sítio. É nele que os moradores assistem às festas religiosas da capela, participam do mutirão, fazem parte de uma vizinhança. E o mais 
importante: embora ocupem lugar geográfico, não são imutáveis, passam por uma dinâmica de crescimento ou de abandono e mudança (QUEIROZ, 1973, p. 50-52). Na vivência comunitária, o sentimento de pertencimento ao grupo passa pelas relações familiares, a parentela e o compadrio.

O afastamento geográfico não pesa sobre as relações familiares. Mesmo se tornando indiretas, ou quase, persistem. Os que partiram conservam os mesmos direitos, quer retornem, quer não; e seus filhos poderão reclamar mais tarde, o apoio que lhes deve a família de que se afastaram seus pais. A parentela tem a ajuda mútua por dever; a reciprocidade é elemento fundamental destas relações. [...] O compadrio segue o mesmo princípio. $\mathrm{O}$ padrinho está ligado ao pai e à mãe de seu afilhado, do mesmo modo que a este. [...] Existem também maneiras variadas de se estabelecer laços de compadrio além do batismo: compadres de fogueira ou de São João, padrinhos da Semana Santa, constituem laços estabelecidos entre indivíduos que voluntariamente desejaram se unir por meio deles. (QUEIROZ, 1973, p. 54).

Estabelecidos vínculos tão fortes de convivência, qual seria a experiência dos camponeses sobre a região? Considerariam imperioso abandonar seu modo de vida para "empregarem-se" nas atividades determinadas pela classe senhorial? As práticas no decorrer do século XIX mostram que não. E permaneceram no século seguinte. Estabeleciam outros vínculos e davam outro sentido para suas atividades. Irineu Pinheiro fez referência ao trabalho de auxílio mútuo, também conhecido por mutirão.

Por termos falado em moradores ou agregados, registremos que no nosso sertanejo sempre dominaram certas tendências de cooperação. Trocam-se frequentemente entre êles dias de serviço, comuns ou adjuntos em que, às vezes, dezenas de homens, auxiliam gratuitamente o seu vizinho nas limpas de suas roças, nas suas colheitas, em outros misteres rurais.

Basta que o dono do trabalho lhes dê o bocado (comida).

Vi certa ocasião no lugar Aroeira, distante três léguas de Missão Velha, um pequeno proprietário tapar a barro, num dia, toda a sua casa, que era grande. Trabalharam oitenta homens que não receberam salários. Deu-lhes apenas, o beneficiado o almôço e a janta. (PINHEIRO, 2009, p. 122).

Como afirma Antonio Candido (2010, p. 81-82), entre os trabalhadores que vivenciavam a condição camponesa, havia uma inevitável solidariedade, a necessidade de ajuda determinava uma rede ampla de relações, ligando uns aos outros, estabelecendo laços de sociabilidade e diversas modalidades de trabalho. Como o mutirão - em que um convoca os demais a fim de ajudá-lo (derrubada, roça, plantio, limpa, colheita, construção). Não há remuneração direta, a não ser a obrigação moral de corresponder ao auxílio. Outra forma era o auxílio vicinal coletivo, quando os vizinhos, percebendo as dificuldades de um deles, combinavam a ajuda, sem aviso prévio. $\mathrm{O}$ 
depoimento de Irineu Pinheiro, que chegou a presenciar o mutirão em meados do século XX, corrobora o que Maria Isaura de Queiroz afirmou sobre as formas de convivência do campesinato brasileiro. Além da ajuda mútua e coletiva sem remuneração em auxílio a um vizinho, outro sentido davam os camponeses ao espaço vivido, predominando a mesma ideia de reciprocidade, conceituada por Queiroz como do ut des, ou seja, "dou para que me dês", baseada na confiança, na palavra empenhada.

Em diferentes condições viviam os trabalhadores no Cariri cearense em meados do século XIX. Rurais ou urbanos, escravizados ou livres, pequenos posseiros ou moradores, negros, brancos, mestiços, alguns com mais recursos, outros vivendo numa situação de pobreza, fugitivos, remanescentes dos povos indígenas e quilombolas, nas mais diversas atividades econômicas e tarefas. Elaboraram sua própria identidade na convivência do espaço, uma experiência muitas vezes sufocada pela classe senhorial. Uma das formas de convivência no espaço regional foi a das comunidades remanescentes de escravos. Comunidades que, mais de um século depois, conseguiram o reconhecimento formal por parte do Estado brasileiro. Cito como exemplo a Comunidade Quilombola Serra dos Chagas, localizada na cidade de Salitre, no extremo oeste da Região do Cariri, próxima à fronteira com o Piauí. Em pleno Cariri, que durante muito tempo se afirmou como predominantemente "branco", a existência de uma comunidade de ex-escravizados negros, que resistiu às pressões e que hoje em dia tem nos seus descendentes a busca pelo resgate de sua história, contribui para superar as antigas afirmações do senso comum. A fonte principal que utilizei para descrever a vida comunitária e a memória daquela comunidade é o "Relatório Antropológico de reconhecimento e delimitação do território da Comunidade Quilombola Serra dos Chagas".

\footnotetext{
A Comunidade Quilombola Serra dos Chagas é uma comunidade tradicional, negra e rural, formada pelos descendentes de quatro famílias negras tradicionais da região da Chapada do Araripe, presumivelmente com ancestrais escravos. Trata-se das famílias-tronco: FAMÍLIA NASCIMENTO (conhecida como Os Titino ou Os Chaga), FAMÍLIA VICENTE (conhecida como Os Vicente), FAMÍLIA JACINTO (conhecida como Os Jacinto) e FAMÍlIA ALENCAR (conhecida como Os Alencar). Essas quatro famílias negras tradicionais se misturaram ao longo do tempo, através de trocas matrimoniais e informais. (MARQUES, 2010, p. 15 - grifos no original).
}

Por meio da memória de seus moradores mais velhos, o relatório aponta as tradições e práticas da comunidade Serra dos Chagas. Uma delas é sobre as origens do grupo. Uma das histórias é a de um negro, que acreditam ser neto ou filho de escravos, 
Manoel Francisco do Nascimento, conhecido por "Chico Novo", considerado o patriarca, que teria migrado de Araripina-PE para a área da comunidade, no último quarto do século XIX e teria se casado com a índia Benedita.

O estudo antropológico aponta os critérios de pertencimento à comunidade quilombola nos dias atuais: o parentesco consanguíneo, o parentesco afim com as famílias-tronco que deram origem à comunidade quilombola, a residência na comunidade ou na área do território, o vínculo formal e a participação efetiva na Associação Quilombola da Serra dos Chagas, a boa convivência e o respeito às regras e normas estabelecidas pela comunidade (MARQUES, 2010, p. 72). Segundo Eurípedes Funes (1995, p. 40), a autopercepção identitária de um grupo descendente ou remanescente de quilombola se dá a partir do próprio grupo, na busca de suas raízes, impregnadas de historicidade, afirmando-se a pertença ao território. E as raízes dessa história estão fincadas na tradição familiar, no trabalho coletivo, na afirmação de uma religiosidade própria, nas práticas cotidianas das atividades agrícolas do Cariri.

O relatório também aponta os aspectos cosmológicos, religiosos e culturais da comunidade. Identifica uma tradição religiosa baseada no catolicismo tradicional do século XIX, mas sem uma prática coletiva da religião católica, sendo mais familiar ou na forma privada. Os vizinhos reúnem-se para atividades nas casas, como novenas, velórios, terços. Para missas ou batismos, tem que se deslocar para a cidade de Salitre. São descritas as festas do passado, uma em honra a São João, no mês de junho, e outra em honra a Nossa Senhora da Conceição, no mês de dezembro. Destaca-se o papel das rezadeiras, capazes de curar determinados males do corpo e da alma. Segundo o autor do relatório, os aspectos culturais são os verdadeiros suportes da identidade étnica dos quilombolas da Serra dos Chagas, ajudando a estabelecer as diferenças culturais entre a comunidade e a sociedade envolvente e circundante (MARQUES, 2010, p. 77).

Já no século XIX, os moradores da Serra dos Chagas estabeleciam sua própria estratégia de produção, baseada nos saberes tradicionais da comunidade camponesa. Uma economia assentada na agricultura de subsistência, com a produção de cereais milho, feijão; hortaliças - abóbora, maxixe, amendoim, quiabo, pepino; frutas melancia, banana, mamão, melão; tubérculos - mandioca, entre outros itens, associada à caça, à pesca e ao extrativismo de madeira e outras plantas, que permanece nos dias atuais. Dessa maneira, o trabalho ali realizado não tinha relação com as demandas econômicas da classe senhorial. 


\section{Considerações finais}

No Cariri da segunda metade do século XIX, a desigualdade social estava permeada por diferenças de cor, sendo que a classe senhorial era nitidamente branca, enquanto que os setores subalternos tinham uma variedade de denominações relacionadas ao fato de não serem brancos, sendo chamados de "pardos", "mulatos", "cabras", "crioulos", "pretos", entre outras denominações. Sobre as comunidades camponesas no Cariri daquele período, persiste nos dias atuais toda uma tradição cultural, religiosa e produtiva. Vive nos sítios, parte considerável da população de trabalhadores. Na segunda metade do século XIX, as trajetórias de vida foram marcadas pelas relações entre essas diferentes comunidades e as demais classes sociais. Existiram aqueles que prosperaram, conseguindo acesso às pequenas posses. Destes, alguns perdiam suas terras e bens por motivo de disputas familiares, ou rivalidades entre senhores, alguma calamidade climática ou epidêmica. Outros não tiveram as mesmas possibilidades e foram obrigados a trabalhar como empregados, em alguns casos, em conjunto com escravizados. Empregavam-se como jornaleiros, ou pediam proteção e moradia a um senhor, passando à condição de "moradores", ou seja, trabalhadores que podiam fazer suas roças em terras senhoriais, construir suas casas de palha nas mesmas propriedades e prestar alguns serviços aos senhores. Não eram condições estáticas.

Tais condições variavam no tempo, dependiam da conjuntura política, econômica, da capacidade de cada sujeito em articular suas demandas, suas lutas, de formar comunidades, de resistir ao domínio senhorial, enfim, de construir suas vidas por si, dentro das possibilidades que se apresentavam. O que é possível inferir de forma mais ampliada é que as percepções sobre como gerir suas vidas e lidar com o trabalho, muitas vezes, distanciavam-se da perspectiva senhorial, podendo levar ao confronto. Nessa luta, as diferentes experiências fizeram um Cariri diverso daquele propalado pelas elites, qual seja, de um "oásis" que seria apenas perturbado pelos hábitos perniciosos dos trabalhadores.

O Cariri vivido refletia as contradições das relações sociais existentes. Idealizado no discurso senhorial como o lugar do refrigério, da fertilidade do solo, da presença das águas de suas fontes, oriundas da Chapada do Araripe, lugar de descanso para o viajante, da generosidade dos senhores, mas era, ao mesmo tempo, espaço do conflito, da diferença de usos da terra, da ociosidade e da propensão à criminalidade da classe subordinada se não houvesse o controle social. A humanidade e a natureza 
determinadas. Da idealização para a representação. Em que pese a identificação dessa construção com um modelo de sociedade pensada pelos senhores ou seus intelectuais, a historiografia que pretenda abordar o Cariri não deve partir de uma interpretação determinista da natureza e, consequentemente, das atividades econômicas. Seria incompleta se considerasse que somente as relações humanas no âmbito social seriam históricas e que, portanto, apenas elas mudassem no decorrer da temporalidade. Ou que as relações econômicas estariam determinadas pelos recursos naturais existentes, como se fossem um dado a priori. O resultado levaria a considerar que as atividades ligadas à pecuária, à agricultura ou ao comércio ocorreriam devido às "oportunidades" naturais do entorno, do espaço, reafirmando o discurso dominante no século XIX. Um local com fontes de água e solo fértil, "naturalmente", seria propício à determinada prática agrícola. Já um terreno com solos mais empobrecidos do ponto de vista da potencialidade produtiva, serviria para as pastagens, por exemplo. A própria ideia de fertilidade seria permanente, a não ser em caso de desastres naturais.

Nesse tipo de abordagem, também o trabalho humano se apresenta de tal maneira. Assim, nesse raciocínio, algumas atividades fariam uso principalmente da mão de obra escrava enquanto outras, "naturalmente", optariam pelo trabalhador livre, de forma que a história estaria submetida a um determinismo econômico ou a alguma espécie de fatalismo. Ainda que fossem descritas uma série de táticas de resistência por parte dos trabalhadores ou, das estratégias desenvolvidas pelos senhores para a exploração, os usos do trabalho, apareceriam como "naturais", quando na verdade são sociais. Se a natureza tem sua transformação intrínseca, não sendo imutável, também a ação humana ocorre historicamente. Na relação entre as sociedades e seu espaço de ação, o procedimento deve ser o de compreender esse mesmo espaço como uma correlação variável no decurso histórico.

Uma história que não é apenas do Cariri, mas que aconteceu também na região, com suas peculiaridades. Envolveu o domínio e apropriação dos recursos naturais, bem como de seres humanos; compreendeu a busca por uma identidade regional que justificasse toda a dominação que ali existiu; exigiu a construção de um discurso sobre o Cariri que acabou sendo repetido através do tempo, tornando-se quase "natural" e até motivo de orgulho para determinados setores da população, qual seja, a que representa a região como sendo o "celeiro" do sertão, com seus "verdes canaviais" e "fontes perenes de água”, onde os viajantes podem descansar depois de percorrer os sertões áridos e quentes. O pretenso projeto civilizador da classe senhorial significou o aumento dos 
estereótipos sobre as classes subordinadas. Da apropriação injusta dos recursos naturais e da autoimagem de bondade e civilizada, os senhores estigmatizaram os mais pobres. Enquanto alguns puderam desfrutar as possibilidades de uma vida de fartura material e de prestígio social, combinados ao poder político, os trabalhadores procuraram diversas formas de resistir, muitas vezes, apenas para poder sobreviver no Cariri. E resistindo, estabeleceram laços de solidariedade, amizade, amor, mesmo que esses sentimentos não surjam na documentação oficial. 


\section{REFERÊNCIAS}

\section{Fontes primárias}

ARQuivo PÚBlico DO ESTADO DO CEARÁ. Câmara Municipal do Crato. Relatório da Câmara Municipal do Crato ao Presidente da Província do Ceará, Ignacio Corrêa de Vasconcelos, em 11 de maio de 1846. Caixa 34, 11/05/1846. fls. 1-2.

ARQuivo PÚBlico DO ESTADO DO CEARÁ. Câmara Municipal do Crato. Ofício da Câmara Municipal do Crato ao Presidente da Província do Ceará, Ignacio Corrêa de Vasconcelos, em 13 de abril de 1847. Caixa 34, 13/04/1847.

CENTRO DE DOCUMENTAÇÃO DO CARIRI. Jornal A Voz da Religião. A Voz da Religião, Cidade do Crato, 30 Out. 1870. p. 3. [Coleção Digital].

CENTRO DE DOCUMENTAÇÃO DO CARIRI. Jornal O Araripe. O Araripe, Cidade do Crato, 07 jul. 1855. p. 2. [Coleção Digital].

CENTRO DE DOCUMENTAÇÃO DO CARIRI. Jornal O Araripe. O Araripe, Cidade do Crato, 14 jul. 1855. p. 1. [Coleção Digital].

CENTRO DE DOCUMENTAÇÃO DO CARIRI. Jornal O Araripe. Carta de A.G., morador de Missão Nova, enviada em 29 de fevereiro de 1856. O Araripe, Cidade do Crato, 1 mar. 1856. p. 2. [Coleção Digital].

CENTRO DE DOCUMENTAÇÃO DO CARIRI. Jornal O Araripe. O Araripe, Cidade do Crato, 10 maio 1856. p. 2. [Coleção Digital].

CENTRO DE DOCUMENTAÇÃO DO CARIRI. Jornal O Araripe. O Araripe, Cidade do Crato, 26 jun.1858. p. 1. [Coleção Digital].

CENTRO DE DOCUMENTAÇÃO DO CARIRI. Jornal O Araripe. O Araripe, Cidade do Crato, 02 abr. 1859. p.1. [Coleção Digital].

PROVÍNCIA DO CEARÁ. Fala de abertura da $1^{\text {a }}$ Sessão da $18^{\circ}$ Legislatura feita pelo Presidente da Província do Ceará, João Antonio de Araujo Freitas Henriques, em 01 de setembro de 1870. p. 36. Disponível em: <http://www.crl.edu/brazil/provincial/cear\%C3\%A1>. Acesso em: 12 mar. 2012.

PROVÍNCIA DO CEARÁ. Relatório do Chefe de Polícia, Henrique Pereira de Lucena, anexo à fala de João Antonio de Araujo Freitas Henriques. 1870. Disponível em: <http://www.crl.edu/brazil/provincial/cear\%C3\%A1>. Acesso em: 12 mar. 2012.

\section{Fontes secundárias}

ABREU, Capistrano de. Caminhos antigos e povoamento do Brasil. Belo Horizonte: Itatiaia; São Paulo: Editora da Universidade de São Paulo, 1988. 
ALBUQUERQUE JÚNIOR, Durval Muniz de. A invenção do nordeste e outras artes. 5. ed. São Paulo: Cortez, 2011.

ALEMÃO, Francisco Freire. Diário de Viagem de Francisco Freire Alemão: Fortaleza-Crato, 1859. Fortaleza: Museu do Ceará; Secretaria de Cultura do Estado do Ceará, 2006.

CANDIDO, Antonio. Os parceiros do Rio Bonito: estudo sobre o caipira e a transformação dos seus meios de vida. 11 a ed. Rio de Janeiro: Ouro sobre Azul, 2010.

CORTEZ, Ana Sara Ribeiro Parente. Cabras, caboclos, negros e mulatos: a família escrava no Cariri Cearense (1850-1884). 2008. Dissertação (Mestrado em História Social) - Universidade Federal do Ceará, Programa de Pós-graduação em História, Fortaleza, 2008.

FIGUEIREDO FILHO, José de. Engenhos de Rapadura do Cariri: documentário da Vida Rural. Fortaleza: Edições UFC, 2010a.

FIGUEIREDO FILHO, José de. História do Cariri. Vol. III (capítulos 10-14). Fortaleza: Edições UFC; Coedição Secult; Edições URCA, 2010 b.

FUNES, Eurípedes Antônio. "Nasci nas matas nunca tive Senhor": história e memória dos mocambos no Baixo Amazonas. Tese (Doutorado em História Social) Universidade de São Paulo, Programa de Pós-graduação em História, São Paulo, 1995.

HAESBAERT, Rogério. Regional-Global: dilemas da região e da regionalização na geografia contemporânea. Rio de Janeiro: Bertrand Brasil, 2010.

INSTITUTO DE ESTRATÉGIA E PESQUISA ECONÔMICA DO CEARÁ. Perfil Básico Regional 2008 - Macrorregião do Cariri/Centro-Sul, 2008. Disponível em: $<$ http://www2.ipece.ce.gov.br/estatistica/perfil_regional/R8_Cariri_Centro_Sul_Ma crorregiao.pdf>. Acesso em: 13 jun. 2009.

MATTOS, Ilmar Rohloff de. O tempo saquarema: a formação do estado imperial. 2. ed. São Paulo: Hucitec, 2011.

MARQUES, José da Guia. Relatório Antropológico de reconhecimento e delimitação do Território da Comunidade Quilombola Serra dos Chagas. SR02/CE, SR-02/F, SR-02/F. Fortaleza: Ministério Do Desenvolvimento Agrário; Instituto Nacional de Colonização e Reforma Agrária, Fortaleza, 2010.

PINHEIRO, Irineu. O Cariri: seu descobrimento, povoamento, costumes. Ed. fac.sim. Fortaleza: FWA, 2009.

QUEIROZ, Maria Isaura Pereira de. O campesinato brasileiro: ensaios sobre civilização e grupos rústicos no Brasil. Petrópolis: Vozes; São Paulo: Ed. da Universidade de São Paulo, 1973. 
REIS JUNIOR, Darlan de Oliveira. Senhores e trabalhadores no Cariri cearense: terra, trabalho e conflitos na segunda metade do século XIX. 2014. Tese (Doutorado em História) - Universidade Federal do Ceará, Centro de Humanidades, Programa de Pós-Graduação em História Social, Fortaleza, 2014.

SOUZA, Simone (Org.). Uma nova História do Ceará. 4 ed. rev. e atual. Fortaleza: Edições Demócrito Rocha, 2007.

WILLIAMS, Raymond. O campo e a cidade: na história e na literatura. Trad. Paulo Henriques Britto. São Paulo: Companhia das Letras, 1989. 